\title{
Corporate Governance Report and Stakeholder View*
}

\author{
Daniela M. Salvioni ${ }^{* *}$, Luisa Bosetti ${ }^{* * *}$
}

\begin{abstract}
The increasing importance recognised to corporate governance, the shift from the dominance of the shareholder view to the prevalence of the stakeholder view, and the necessity to recover approval on companies' actions have stressed the opportunity of complete disclosure about corporate governance structures and performances.

The research is founded on an international comparison and is finalised to verify: the existence of principles and recommendations concerning the corporate governance communication; the real quality of corporate governance communication published by some companies, operating in the same sector but in different countries; the effort needful to reach a formal and substantial shared model of communication.
\end{abstract}

Keywords: Corporate Governance; Corporate Governance Communication; Corporate Governance Report; Stakeholder View; Transparency

\section{Stakeholder View and Corporate Governance Communication}

Corporate governance is nowadays widely discussed. This debate, begun at the end of the last century and still far from conclusion, is focalised on the search for optimal requirements of effectiveness, propriety and transparency.

The studies on corporate governance have distant origins ${ }^{1}$, but a revision of governance principles from a global point of view has been just recently proposed, adopting a wide-ranging and shared approach of uniformity and contemporaneous respect of national peculiarities. This approach is based on a broad notion of responsibility and on a modern consideration of the links existing between the company's durable success and the equitable composition of all stakeholders' interests.

The industrialised countries are today searching for optimal models of governance, characterised by reliability and transparency. Particularly, institutions,

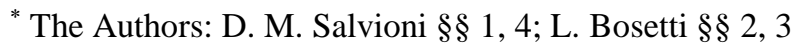

** Full Professor of Business Administration, University of Brescia (salvioni@eco.unibs.it)

*** Lecturer of Business Administration, University of Brescia (bosetti@eco.unibs.it)
}

Edited by: ISTEI - University of Milan-Bicocca

ISSN: 1593-0319

Salvioni Daniela M., Bosetti Luisa, Corporate Governance Report and Stakeholder View, Symphonya. Emerging Issues in Management (symphonya.unimib.it), n. 1, 2006, pp. 24-46

http://dx.doi.org/10.4468/2006.1.03salvioni.bosetti 
scholars and firms tend to give emphasis to: governance decisions, which determine proper relations among resources, activities and performance; the ability to develop positive stakeholder relations, which is connected to governance decisions, actions and communications ${ }^{2}$.

The increasing importance recognised to corporate governance, the shift from the dominance of the shareholder view to the prevalence of the stakeholder view, and the necessity to recover approval on companies' actions have stressed the role of corporate communication. In particular, periodical, clear and complete disclosure about corporate governance structures and forms of actualisation seems to be suitable for this new situation ${ }^{3}$.

In fact, the establishment of effective relationships with the stakeholders is strongly influenced by the ability to offer concrete, understandable, true and exhaustive answers to the stakeholders' need of information. In this sense, the corporate governance evolution and the integrated concept of responsibility (considering legal, economic, social and environmental dimensions) have produced a selected enlargement of corporate communication. In recent years, in addition to the traditional financial disclosure, many other kinds of reporting have been divulged: the social report, the environmental report, the sustainability report, the corporate governance report, the directors and top managers' remuneration report, the integrated report, etc.

Moreover, new ways of information spreading have been sought in order to facilitate access to the messages and well-timed diffusion. In this regard, the development of ICT guarantees important help, permitting the firms to eliminate spatial and time barriers, to improve information symmetry among all the stakeholders and to accelerate international convergence. Especially, the existence of a corporate website section dedicated to investor relations (or stakeholder relations) ensures the availability of information that can be systematically updated by the company and consulted by each stakeholder.

The demand for transparency and effectiveness of corporate governance communication is higher as concerns listed companies, because they involve wide financial interests; furthermore, their correct behaviour strengthens the legitimacy of national stock exchanges all over the world. In this regard, the market regulators of different countries have assumed a proactive role in the improvement of corporate disclosure.

For some years, attention has been specifically focalised on the corporate governance report. This document contains details about: composition, appointment, remuneration and role of corporate governance bodies; the internal control systems supporting the governance; related parties transactions and potential collusions; confidential information handling, information symmetry and internal dealing; investor relations.

Therefore, the corporate governance report tends to be an essential document for brief information on corporate governance structures and processes. Its publication is voluntary, although it is recommended by specific institutions, and it signals the directors' orientation towards transparency and their intention to establish effective relationships with all the company stakeholders.

Of course, recommendations promoted by the stock exchange regulators are not always respected by companies; moreover, the nature of initiatives to orient the 
company behaviour and the actual level of implementation are really different from a country to another, even considering just the industrialised ones. Consequently, it is interesting to realise a comparison among Italy, France, Great Britain, Germany, Spain, the United States of America and Japan, specifically finalised to verify: the existence of principles and recommendations concerning the corporate governance report; the real quality of corporate governance reports published by some companies, operating in the same sector but in different countries.

In particular, the analysis regards eight electric firms, listed on the stock exchanges of the countries considered in the research. The selection of public utilities companies is due to the importance of corporate governance communication in their context. Indeed, it is fundamental for these firms to compose equally: on the one hand, protection of public interest connected to the nature of the services provided and sometimes to the role of the State as a stockholder; on the other hand, entrepreneurial autonomy and value creation in the interests of all the company stakeholders. Finally, the public utility sector shows clear phenomena of globalisation and it takes part to the global social and environmental development.

\section{Recommendations on Corporate Governance Communication}

The general interest in corporate governance communication, manifested by many institutions for market regulation and firm surveillance, has produced very different attitudes. Specific rules on corporate governance communication have been established worldwide, in order to facilitate the knowledge and evaluation of companies, especially of the listed ones. Nonetheless, the penetration of these rules in companies' information systems is really diversified, partly as a consequence of the level of detail adopted by the promoting institutions in their recommendations. Furthermore, today it is still quite difficult to compare corporate governance communications of companies from different countries; moreover, there is significant diversity in each national context too.

Three major approaches have been used by regulators all over the world to influence the corporate governance communication of listed companies and, indirectly, of all other firms that want to be transparent. Indeed, a survey of different countries permits distinguishing among (Table 1):

a) countries with formal and substantial recommendations to orient companies in drawing up their corporate governance reports;

b) countries where regulators indicate the most important information on corporate governance that companies should detail in their financial report (typically, in the annual report);

c) countries where neither special recommendations about an independent corporate governance report exist, nor a specific chapter on corporate governance is required in the annual report.

Italy and Spain are two of the countries with formal and substantial recommendations concerning the corporate governance report. In both countries, listed companies are expected to publish all relevant details on their corporate governance in a specific annual document, following a pre-established outline ${ }^{4}$. 
France, Great Britain and the United States give larger autonomy to the companies with reference to corporate governance communication: stock exchange regulators and surveillance authorities define only the essential information that must complete financial reports or other mandatory documents (the reference document, the annual report and the proxy statement ${ }^{5}$ ).

Finally, interest in corporate governance communication does not seem to be as high in Germany and Japan as in the previous countries: there are neither specific recommendations for an independent report nor a list of details on corporate governance to be inserted in the annual report ${ }^{6}$.

With reference to the board of directors functioning, all the countries with specific recommendations require a complete description of internal committees ${ }^{7}$, as regards composition, powers and meetings. However, there are also national peculiarities: for instance, the United States privilege the communication on the audit committee, while in the other countries this is just one of the bodies that companies should illustrate.

The countries investigated in this research usually require firms to divulge an annual self-assessment concerning the board of directors activity; in some cases (France and the United States) this evaluation is also accompanied by the opinion of a company's control body.

Regarding the remuneration system for directors and executive officers, Spain pays higher attention than Italy: indeed, the corporate governance report of Spanish companies must describe the rules for compensation assignment, as well as details on the global compensation paid to each category of directors. These same types of information must be also published by French companies, which must indicate the individual remunerations too. On the contrary, compensation reporting is not expressly included in the guidelines on corporate governance communication of the Anglo-Saxon countries.

Recommendations on investor relations determine some uniformity of behaviour, but differences in corporate governance communication.

As concerns the countries with specific recommendations on corporate governance disclosure, it is possible to identify some topics that are considered fundamental in order to guarantee transparency on direction and control principles, structures and processes. However, national events can produce diverse emphasis on different aspects of corporate governance: in this regard, the United States are an interesting example, because their recommendations on corporate governance communication tend mostly to warrant a proper description of the company's internal control system and to assure the financial disclosure reliability ${ }^{8}$.

First of all, the corporate governance communication should clarify the composition of governance and control bodies, their functioning and compensation.

With reference to governance structures, Italy and Spain require in-depth information in the corporate governance report about the board of directors or the management board, with personal details (as the members' names), as well as the type of charge (outside directors, independent directors), roles, delegation of powers, meetings, etc. The French recommendations are also detailed, even if companies are not obliged to publish a separate report.

Recommendations of Great Britain and the United States are less strict: for instance, British listed firms should disclose just the most important directors' and 
officers' names (chairman, CEO, lead independent director ${ }^{9}$, etc.) and explain how the non-executive directors become conscious of the stakeholders' expectations; instead, US companies have to pay attention to the role of independent director and favour the dialogue among the chairman, the directors and the stakeholders.

The spread of information on internal control and risk management is strongly recommended by all the countries analysed in this study, which sometimes also require the audit committee or the board of directors to realise and publish an evaluation of the internal procedures' effectiveness and efficiency. Furthermore, US firms should describe their code of ethics, that is to say an essential internal control instrument to orient directors' and officers' behaviour and particularly direct to persons responsible for the financial disclosure.

Proper corporate governance is based on the equitable treatment of all expectations converging into the firm. In this regard, the external communication should demonstrate that no member of the company's bodies or relevant shareholder has directly or indirectly taken advantage from commercial, financial or asset-involving operations in which the company has been the counterpart. Nevertheless, only Italy, Spain and France recommend companies to explain related parties transactions in their corporate governance disclosure.

The functioning of the general meeting of shareholders should be comprehensively illustrated, with details on the procedures for improving shareholder participation (for example, by means of web conference calls) and proxy voting. Italian and Spanish recommendations are the most detailed on these issues.

Many other elements can be divulged in order to better the effectiveness of listed companies' corporate governance communication, although not all the regulators and supervisors provide for them; moreover, these further details can be differently arranged in relation to how corporate governance systems are actualised in each country. For instance:

- Italian recommendations on the corporate governance report consider also the board of auditors ${ }^{10}$ and promote transparency on the procedures for confidential information handling;

- Spanish companies are required to explain their ownership structure;

- French firms should clarify which principles inspire their strategies of communication to the financial market, especially towards analysts and the specialised press;

- in Great Britain, directors and statutory auditors must produce a declaration concerning accounting procedures and checks on their correctness; moreover, the statutory auditor independence must be reaffirmed if the auditors offer also consultancy to the company;

- finally, US firms must state that they have adopted an internal code of corporate governance, which must be prepared by each company with autonomy, but respecting the generally accepted practices of corporate governance.

It is interesting to underline that Italian, French, British, German and Spanish firms are also influenced by EU directives, so their corporate governance communication could acquire higher uniformity in the future. Modifications of the 
current situation could be produced by possible changes of ownership, agreements and M\&A involving different stock exchanges.

Table 1: Recommendations on Corporate Governance Disclosure: an International Comparison

\begin{tabular}{|c|c|c|}
\hline & Country and Year of Recommendations & Documents \\
\hline 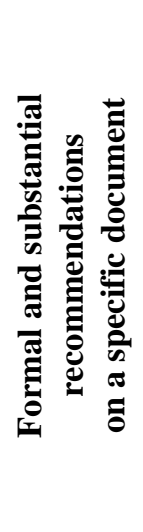 & $\begin{array}{l}\text { ITALY } \\
\text { - Borsa Italiana SpA, Guidelines on annual } \\
\text { corporate governance reports, March } 2002 \\
\text { and February } 2003 \text {. } \\
\text { - Assonime - Emittenti Titoli SpA, Handbook } \\
\text { on Corporate Governance Reports, February } \\
2004 \text {. } \\
\text { SPAIN } \\
\text { - Aldama Report, January } 2003 \text {. } \\
\text { - Ministry of Economy, Act } 26 / 2003 \text {. } \\
\text { - Comisión Nacional del Mercado de Valores, } \\
\text { Circular } 1 / 2004 \text {. }\end{array}$ & $\begin{array}{l}\text { SPAIN } \\
\text { Corporate governance } \\
\text { report. }\end{array}$ \\
\hline 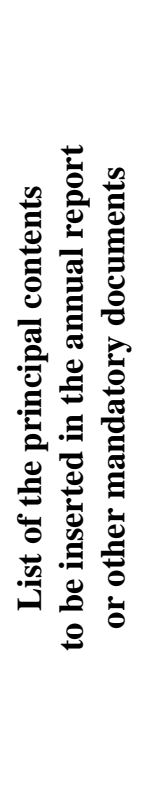 & $\begin{array}{l}\text { FRANCE } \\
\text { - COB, Le Document de référence. Guide } \\
\text { d'information, August 2002. } \\
\text { - COB, Bulletin Mensuel, n. 377, March 2003. } \\
\text { - Loi de sécurité financière (Law 2003-706, } \\
\text { Integration to the Mercantile Law), August } \\
2003 \text {. } \\
\text { UNITED KINGDOM } \\
\text { - Financial Reporting Council, The Combined } \\
\text { Code on Corporate Governance, July 2003. } \\
\text { - Financial Reporting Council, Internal Control. } \\
\text { Revised Guidance for Directors on the } \\
\text { Combined Code, October 2005. } \\
\text { THE UNITED STATES OF AMERICA } \\
\text { - Sarbanes-Oxley Act (Sections 404, 406, 407), } \\
\text { July 2002. } \\
\text { - NYSE's Listed Company Manual (Section } \\
\text { 303A), November } 2004 \text {. }\end{array}$ & $\begin{array}{l}\text { THE UNITED STATES } \\
\text { OF AMERICA } \\
\text { Annual report and proxy } \\
\text { statement. }\end{array}$ \\
\hline 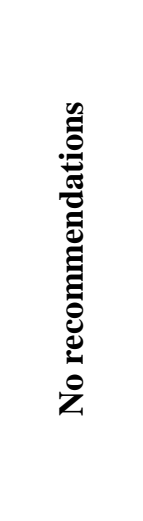 & $\begin{array}{l}\text { GERMANY } \\
\text { The law ('KonTraG') only demands an annual } \\
\text { declaration of compliance of the corporate } \\
\text { governance system with the model provided by } \\
\text { the German corporate governance code, and that } \\
\text { eventual derogations are explained. } \\
\text { JAPAN } \\
\text { There aren't recommendations about corporate } \\
\text { governance disclosure. The Japanese corporate } \\
\text { governance code (April 2004) generically } \\
\text { stimulates companies to be transparent in their } \\
\text { communication to the stakeholders. }\end{array}$ & $\begin{array}{l}\text { JAPAN } \\
\text { Annual report. }\end{array}$ \\
\hline
\end{tabular}


Particularly, the 2004/913/EC recommendation stimulates the information on the remuneration of a listed company directors. In this recommendation, the European Commission establishes that each EU member state must fix the most adequate rules for the communication of compensation, as well as for its composition; this latter is the result of mixing fixed components with variable ones (in connection to the achievement of corporate or individual goals, and sometimes represented by stock grants and stock options). Each state can require a new specific remuneration statement or the insertion of the above-mentioned information in an existent document $^{11}$, as the corporate governance report or the annual report, whose section on management discussion and analysis already contains some details on directors' and officers' remunerations.

The previous considerations permit us to affirm that different recommendations exist in diverse countries, even if they belong to the European Union and they are characterised by similar corporate governance systems as concerns the exercise of control on the company ('outsider systems' or 'insider systems') and the relations between direction and control bodies in the firm ('one-tier systems' or 'two-tier systems') ${ }^{12}$.

$\square$ The distinction between outsider and insider systems derives from the two types of control on management and company results: from the outside, through efficient financial markets, or from the inside, by means of persons interested in maintaining a durable relationship with the firm.

The outsider system (or market-oriented system) is typical of economic contexts with a lot of listed corporations, whose ownership is highly fragmented and diffuse and where the shareholders' interests can conflict with the managers' interests: indeed, these two categories tend not to agree, since investors aren't interested in governing the company, being instead attracted by dividends and value creation. The outsider system is effective when both corporate governance bodies and investors behave correctly and ethically, and when investors can contest the control of the company with the current shareholders buying their stocks on the financial market.

On the contrary, insider systems are characterised by scarcely developed financial markets, concentrated and stable shareholding, cross-holding and other important financial relationships between firms and banks. In such contexts, it is essential to control the management from the inside, because the stickiness of financial markets - where only a small part of the firm equity is traded-does not permit takeovers and the consequent substitution of managers. In the insider systems, managers are therefore controlled by a corporate body appointed by the most relevant stakeholders, selected on the grounds of their risk exposure and the importance of the resource they have conferred to the company.

However, historic and economic events of the countries with an insider system have contributed to the development of two partially different forms. Despite of the mentioned common features, we can distinguish between: the Rhine insider system, characterised by strong participation 
to the control activity by banks and employees; the Latin insider system, where managers are controlled by the major shareholder thanks to his influence on the board of directors.

As regards the distribution of powers among the corporate bodies, the governance systems can have one or two levels. Generally speaking, direction and control activities should be assigned to different bodies or persons, in order to provide stronger guarantees of equitable satisfaction of all the stakeholders' expectations.

National laws and codes of best practices offer diverse solutions concerning the separation of direction and control functions. In fact, it is possible to identify:

1) corporate governance systems in which the powers of direction and control are assigned to different persons belonging to the same body appointed by the shareholders: these systems are named 'one-tier systems' or 'unitary systems';

2) corporate governance systems with two separate bodies: one exercising the direction function, and the other exercising the control function. Even if the two bodies are formally divided, they interact when the control body realises its supervision on the direction body, and sometimes gives it specific guidelines. The rules of body appointment (as described in the continuation) let us adopt the expressions 'dual system' and 'two-tier system'.

As concerns the countries investigated in this article, the US corporate governance system and the British one are similar, since they are both outsider systems. Moreover, US and British companies are directed and controlled by a unitary body, the board of directors, which is mostly composed of non-executive and independent directors with orientation, supervision and control responsibilities. In the other European countries, as well as in Japan, the high influence of specific stakeholder categories on the establishment of stable majorities, compared with the weak role of financial markets, has determined the development of insider systems of corporate governance.

The allocation of powers to corporate bodies can be anyway very different, sometimes among companies of the same country too.

Spain is characterised by a one-tier system, where powers are attributed to the board of directors ('consejo de administración'). This body comprises diverse types of directors, among whom the direction and surveillance functions are divided: the executive directors, the proprietary ones and the independent ones.

$\square$ In France, companies can adopt the one-tier system (the most diffused one) or the two-tier system. In the case of one-tier system, the shareholders appoint the board of directors ('conseil d'administration'), with direction and control functions. The board is led by an executive chairman (named 'président-directeur général', PDG), who exercises 
wide managerial powers and represents the company in external relationships. In the case of two-tier system, the shareholders appoint the supervisory board that is responsible for watching over the management. Direction is assigned to the executive board ('directoire') and its president, both nominated by the supervisory board.

$\square$ Germany is characterised by the two-tier system; the 'Aufsichtsrat' and the 'Vorstand' are respectively the supervisory board and the management board. Their composition is established by law in order to guarantee that the most important categories of stakeholders are adequately represented. Indeed, the supervisory board is appointed by the shareholders and the employees. Banks take part directly in the nomination procedure too, because they are shareholders of the company and they also vote by proxy, instead of their customers (composed of small savers). Therefore, the supervisory board should provide general protection to all expectations converging into the firm, which is considered as a social organisation. The supervisory board appoints and removes the management board, whose activities it formally and substantially verifies.

$\square$ In Italy, the law provides for three corporate governance models, in the light of the companies law reform of 2003: the traditional dual model and two new ones (the one-tier model and the two-tier model).

In the traditional model - still the most adopted today - the board of directors and the board of auditors exercise administrative and control functions respectively. Since these bodies are separate and both appointed by the shareholders, the Italian traditional system of corporate governance can be considered as a 'dual horizontal system'.

In the one-tier system, all powers are assigned to the board of directors. Anyway, surveillance is especially conducted by non-executive and independent members.

In the two-tier system, the shareholders appoint the supervisory board that in turn nominates the management board: the two bodies are totally separate and develop different functions. A peculiarity of the Italian twotier model is that, unlike the German case, it does not provide for employee involvement in appointing the supervisory board.

$\square$ In Japan, since 2003 companies have been free to choose between the traditional system of corporate governance (similar to the Italian traditional one) and the one-tier 'committee system'. In the Japanese traditional system, the shareholders appoint the board of directors, led by an executive president (named 'shacho'), and the board of auditors (named 'kansayaku'). In the one-tier committee system the shareholders appoint the board of directors, charged with all the powers; the board of directors establishes three proposing and consultative internal committees concerning audit, remuneration and nomination. 
In all the systems described, external statutory auditors ascertain the validity and reliability of financial information. In the case of listed companies, this task is attributed to an audit firm.

Certainly, recommendations stimulate the improvement of corporate governance disclosure. The existence of well-structured and detailed instructions induce the firms - particularly, the listed companies - to arrange and spread messages that are at least consistent with the required ones.

However, even in the presence of instructions, the effectiveness of corporate governance communication tends to depend on the culture that characterises the corporate governance bodies, with specific reference to transparency. In this regard, it is relevant to analyse the actual behaviour of companies operating in the abovementioned countries, in order to verify:

- the usefulness of recommendations on corporate governance disclosure;

- the communication on corporate governance existing in fact.

\section{Corporate Governance Communication}

The effectiveness of corporate governance communication depends on the firms' choices within laws and recommendations existing in their own operational environment. Therefore, it is interesting to compare some homogeneous companies of the above-mentioned countries.

As introduced in paragraph 1, this analysis considers eight of the major energy listed firms. More exactly, two of them are listed on the Italian stock exchange, and each of the others is listed on the national financial market of its own country: Spain, France, Great Britain, Germany, the US and Japan. Each company should consequently respect a specific corporate governance code, as requested by its stock exchange.

The selection of energy sector is justified not only by the typical characters of public utilities companies, but also by the dimensions of these firms, which often operate abroad and raise capital in foreign markets too. This increases the relationships of the companies with their stakeholders and imposes to satisfy wider information expectations. Moreover, in some countries the energy firms have been recently involved in privatisation and listing processes, which have deeply modified the corporate governance system, the role of the former public owner, as well as the manner of managing external approvals.

The analysis of the corporate governance communication refers to the aspects described in paragraph 2 as common to all the corporate governance codes; the same are considered in the recommendations promoting the improvement of corporate governance disclosure. Furthermore, the research aims at verifying the existence of detailed information related to country peculiarities.

The Table 2 contains the list of companies and the documents analysed for each of them. The documents referred to the year 2005 and have been collected from the company websites. 
Table 2: Companies and Documents Considered in the Research

\begin{tabular}{lccc}
\hline \multicolumn{1}{c}{ Company } & $\begin{array}{c}\text { Country } \\
\text { of origin }\end{array}$ & $\begin{array}{c}\text { Country } \\
\text { of listing }\end{array}$ & $\begin{array}{c}\text { Document analysed } \\
\text { (year 2005) }\end{array}$ \\
\hline Enel & Italy & Italy, USA & Corporate governance report \\
\hline Edison & Italy & Italy & Corporate governance report \\
\hline Iberdrola & Spain & Spain & Corporate governance report \\
\hline $\begin{array}{l}\text { Eléctricité de France } \\
\text { (EDF) }\end{array}$ & France & France & Document de référence \\
\hline $\begin{array}{l}\text { British Energy Group } \\
\text { (BEG) }\end{array}$ & Great Britain & Great Britain & Annual report \\
\hline Aquila & USA & USA & Proxy statement, Annual report \\
\hline RWE & Germany & Germany & Annual report \\
\hline Chubu & Japan & Japan & Annual report \\
\hline
\end{tabular}

Edison is a particular case in the group of companies: indeed, this firm has Italian origins, but it is currently controlled by Italian and French shareholders ${ }^{13}$ that have defined the rules of corporate governance by means of a shareholders' agreement. The agreement - which is briefly described in Edison corporate governance report follows the fundamental rules of the Italian code of corporate governance.

The most important results of the investigation are illustrated below.

\section{a) Introduction to the Corporate Governance System and Adoption of the Code of Best Practice}

Brief and immediate information can be very helpful for foreign stakeholders, whose knowledge about corporate governance in other countries could be limited. In a similar way, firms should clearly indicate the system they have adopted when the law lets them choose among two or more, as in Italy, France and Japan. In this regard, the two Italian companies and the French one offer adequate information in the initial part of their report, specifying the adoption of the traditional Italian system and the one-tier system respectively; on the contrary, the Japanese company is really vague as concerns its horizontal dual system, characteristic of the country (Table 3). All other firms have implemented their typically national corporate governance system.

Each firm - except Chubu - states the compliance with the corporate governance code and/or the law of its own country of origin, or with the rules adopted in other countries where the company is listed (as in the case of Enel) or holds a significant commercial position. Chubu specifies only the key elements for the improvement of its corporate governance structures and procedures, adopting an approach based on correctness and transparency ${ }^{14}$. 
Table 3: Introduction to the Corporate Governance System and Adoption of the Code of Best Practice ${ }^{15}$

\begin{tabular}{lcccccccc}
\hline & Enel & Edison & Iberdrola & EDF & BEG & Aquila & RWE & Chubu \\
\hline $\begin{array}{l}\text { Declaration of the corporate } \\
\text { governance system }\end{array}$ & $\mathrm{x}$ & $\mathrm{x}$ & & $\mathrm{x}$ & & & & \\
\hline $\begin{array}{l}\text { References to the law or to } \\
\text { codes of best practices }\end{array}$ & $\mathrm{x}$ & $\mathrm{x}$ & $\mathrm{x}$ & $\mathrm{x}$ & $\mathrm{x}$ & $\mathrm{x}$ & $\mathrm{x}$ & \\
\hline $\begin{array}{l}\text { Declaration of compliance } \\
\text { with the codes }\end{array}$ & $\mathrm{x}$ & $\mathrm{x}$ & $\mathrm{x}$ & $\mathrm{x}$ & $\mathrm{x}$ & $\mathrm{x}$ & $\mathrm{x}$ & \\
\hline
\end{tabular}

\section{b) The Board of Directors}

Information on the board of directors (or the management board, in the case of the German firm RWE) is differently structured in the documents analysed (Table 4).

Table 4: Information on the Board of Directors Composition and Members

\begin{tabular}{|c|c|c|c|c|c|c|c|c|}
\hline & Enel & Edison & Iberdrola & EDF & BEG & Aquila & RWE & Chubu \\
\hline Members' names & $\mathrm{x}$ & $\mathrm{x}$ & $\mathrm{x}$ & $\mathrm{x}$ & $\mathrm{x}$ & $\mathrm{x}$ & $\mathrm{x}$ & $\mathrm{x}$ \\
\hline Members' CV & $\mathrm{x}$ & & $\mathrm{x}$ & $\mathrm{X}$ & $\mathrm{X}$ & $\mathrm{x}$ & & \\
\hline $\begin{array}{l}\text { Expiry (or duration) of } \\
\text { mandate }\end{array}$ & $\mathrm{x}$ & $\mathrm{x}$ & & $\mathrm{x}$ & $\mathrm{x}$ & $\mathrm{x}$ & & \\
\hline $\begin{array}{l}\text { Highest/lowest number of } \\
\text { members }\end{array}$ & $\mathrm{x}$ & $\mathrm{X}$ & $\mathrm{x}$ & & & & & $\mathrm{X}$ \\
\hline $\begin{array}{l}\text { Executive and non-executive } \\
\text { directors }\end{array}$ & $\mathrm{X}$ & $\mathrm{X}$ & $\mathrm{x}$ & & $\mathrm{x}$ & $\mathrm{x}$ & & \\
\hline Independent directors & $\mathrm{x}$ & $\mathrm{x}$ & $\mathrm{x}$ & & $\mathrm{x}$ & $\mathrm{x}$ & & \\
\hline Directors' roles and tasks & $\mathrm{x}$ & $\mathrm{x}$ & $\mathrm{x}$ & $\mathrm{x}$ & & & & \\
\hline \multirow[t]{2}{*}{ Other positions held } & $\mathrm{X}$ & $\mathrm{x}$ & $\mathrm{x}$ & $\mathrm{X}$ & $\mathrm{x}$ & $\mathrm{X}$ & $\mathrm{x}$ & \\
\hline & 8 & 7 & 7 & 5 & 6 & 6 & 2 & 2 \\
\hline
\end{tabular}

The unique detail given by all the companies is the composition of the board of directors. Eléctricité de France and Enel publish further information about appointment, specifying which directors have been nominated by the State: indeed, even if these companies have been privatised, the State still holds relevant shares of capital (more than $70 \%$ in the French firm and more than $30 \%$ in the Italian one). Eléctricité de France underlines its duty to appoint one or two directors coming from political institutions, even local, or chosen among experts in energy issues. Enel reminds the power of the State - never exercised until now - to appoint one further director, without rights of vote, as established by the Italian privatisation law and the company by-law.

Individual details about directors are rare: in fact, three companies (Edison, RWE and Chubu) omit to publish the $\mathrm{CV}$ in the corporate governance report or in the specific section of the annual report ${ }^{16}$.

The disclosure is often incomplete in relation to the mandate expiry or duration (indicated by five companies out of eight) and the highest and lowest number of directors (specified by four firms, including the Japanese one that has fixed at twenty members the ideal dimension of the board in order to promote an effective dialogue). 
As concerns the capacity of non-executive director and independent director, some more details should be disclosed ${ }^{17}$. Particularly, the information divulged by Eléctricité de France can be improved with reference to independence: indeed, the firm declares that it has adopted different criteria of independence respect to the ones established in the French code of best practice, but it does not describe them. On the opposite, Iberdrola pays attention in communicating the capacity of each director, distinguishing between executive and non-executive members and classifying these latter as proprietary directors, independent directors and others, and it also explains the reasons: this richness of details is promoted by the recommended outline of corporate governance report.

All the companies, with the exception of Chubu, give information about the positions assumed by their directors in other firms or organisations, according to the best practice in order to clarify interlocking directorships.

The communication about the functioning of the board is shown in the Table 5 .

Some of the documents analysed (British Energy Group, Aquila, RWE and Chubu) are often defective in relation to the information about powers and functions of the board of directors and its members. Enel, Edison, Iberdrola and Eléctricité de France pay instead attention to these details, in particular as concerns the chairman and CEO (who are sometimes the same person). It is interesting that three of the mentioned companies have to publish their corporate governance report on the basis of specific recommendations.

As regards the board meetings, all the firms subject to recommendations disclose the number of meetings and the attendance of each director. Consistently with the recommendations, the two Italian companies are the most careful, specifying also that the board of auditors and a magistrate of the Court of Accounts (in the case of Enel) take part in the board meetings.

Table 5: Information on the Functioning of the Board of Directors

\begin{tabular}{|c|c|c|c|c|c|c|c|c|}
\hline & Enel & Edison & Iberdrola & EDF & BEG & Aquila & RWE & Chubu \\
\hline Board's functions and powers & $\mathrm{X}$ & $\mathrm{X}$ & $\mathrm{X}$ & $\mathrm{x}$ & & & & \\
\hline $\begin{array}{l}\text { Directors' tasks and } \\
\text { responsibilities }\end{array}$ & $\mathrm{x}$ & $\mathrm{x}$ & $\mathrm{x}$ & $\mathrm{x}$ & & & & \\
\hline $\begin{array}{l}\text { Board's exclusive } \\
\text { responsibilities }\end{array}$ & & $\mathrm{x}$ & & $\mathrm{x}$ & $\mathrm{x}$ & & & \\
\hline $\begin{array}{l}\text { Board's right to be informed by } \\
\text { managing directors and the } \\
\text { executive committee }\end{array}$ & $\mathrm{x}$ & & $\mathrm{x}$ & $\mathrm{x}$ & & & & \\
\hline Number/frequency of meetings & $\mathrm{x}$ & $\mathrm{x}$ & $\mathrm{x}$ & $\mathrm{x}$ & $\mathrm{x}$ & $\mathrm{x}$ & & \\
\hline Attendance at meetings & $\mathrm{x}$ & $\mathrm{x}$ & $\mathrm{x}$ & $\mathrm{x}$ & $\mathrm{x}$ & $\mathrm{x}$ & & \\
\hline $\begin{array}{lll}\text { Abstention } & \text { from } & \text { specific } \\
\text { decisions } & & \end{array}$ & $\mathrm{x}$ & $\mathrm{x}$ & $\mathrm{x}$ & & $\mathrm{x}$ & & & \\
\hline & 6 & 6 & 6 & 6 & 4 & 2 & $\mathbf{0}$ & $\mathbf{0}$ \\
\hline
\end{tabular}

Just four companies (from Italy, Spain and Great Britain) give information on the directors' duty of abstention from voting in decisions on related parties transactions that involve their personal interests, as well as in decisions concerning their remuneration. 
The information on internal committees charged with tasks of giving advice and making proposals varies according to the nature of each committee. Anyway, all the companies tend to communicate the committees' composition, number of meetings, attendance and powers ${ }^{18}$, but they rarely describe the activities the committee has actually realised in the year. This is valid for the expressly recommended committees (executive, nomination, remuneration and audit), but also for the others ${ }^{19}$. The Italian firms pay usually more attention to internal committees than the other companies.

The nomination committee (Table 6) exists in three firms, all characterised by the one-tier system (British Energy Group, Aquila and Iberdrola ${ }^{20}$ ). Considering the companies without a nomination committee, Edison explains that it is not necessary since the board of directors appointment is regulated by a shareholders' agreement, described in the corporate governance report ${ }^{21}$. Other four firms illustrate their nomination procedure, as requested in their national recommendations.

More details have been disclosed as concerns the remuneration committee (Table 7). Eléctricité de France offers a description of this committee, although it did not function in 2005: indeed, the company declares that the remuneration committee will start to operate in 2006.

Chubu is the only firm in the report of which there is no information on the remuneration committee. However, the reason could be that the traditional Japanese system of corporate governance does not provide for internal committees.

Table 6: Information on Appointment Procedures and the Nomination Committe $^{22}$

\begin{tabular}{|c|c|c|c|c|c|c|c|c|}
\hline & Enel & Edison & Iberdrola & EDF & BEG & Aquila & RWE & Chubu \\
\hline $\begin{array}{l}\text { Description of appointment } \\
\text { procedure }\end{array}$ & $\mathrm{x}$ & $\mathrm{x}$ & $\mathrm{x}$ & & $\mathrm{x}$ & $\mathrm{x}$ & & \\
\hline $\begin{array}{l}\text { Existence of the nomination } \\
\text { committee }\end{array}$ & & & $\mathrm{x}$ & & $\mathrm{x}$ & $\mathrm{X}$ & & \\
\hline Composition & & & $x$ & & $x$ & $x$ & & \\
\hline Number of meetings & & & $x$ & & $x$ & $x$ & & \\
\hline Attendance & & & & & $x$ & & & \\
\hline Powers & & & $x$ & & $x$ & $x$ & & \\
\hline \multicolumn{9}{|l|}{ Activities actually realised } \\
\hline & 1 & 1 & 5 & 0 & 6 & 5 & 0 & 0 \\
\hline
\end{tabular}

Table 7: Information on the Remuneration Committee

\begin{tabular}{|c|c|c|c|c|c|c|c|c|}
\hline & Enel & Edison & Iberdrola & EDF & BEG & Aquila & RWE & Chubu \\
\hline $\begin{array}{l}\text { Existence of the remuneration } \\
\text { committee }\end{array}$ & $\mathrm{x}$ & $\mathrm{x}$ & $\mathrm{X}$ & & $\mathrm{x}$ & $\mathrm{x}$ & $\mathrm{x}$ & \\
\hline Composition & $x$ & $x$ & $x$ & & $x$ & $x$ & $x$ & \\
\hline Number of meetings & $x$ & $x$ & $x$ & & $x$ & $x$ & $x$ & \\
\hline Attendance & $x$ & $x$ & & & $x$ & & & \\
\hline Powers & $x$ & $x$ & $x$ & & $x$ & $x$ & & \\
\hline Activities actually realised & $x$ & $x$ & & & $x$ & & $x$ & \\
\hline & 6 & 6 & 4 & $\mathbf{0}$ & 6 & 4 & 4 & $\mathbf{0}$ \\
\hline
\end{tabular}


The executive committee prevails in non-Italian companies, where it can also operate as a strategic and investment committee. The most diffused details regard its composition and powers (Table 8).

Table 8: Information on the Executive Committee

\begin{tabular}{|c|c|c|c|c|c|c|c|c|}
\hline & Enel & Edison & Iberdrola & EDF & BEG & Aquila & RWE & Chubu \\
\hline $\begin{array}{l}\text { Existence of the executive } \\
\text { committee }\end{array}$ & & & $\mathrm{x}$ & $\mathrm{x}$ & $\mathrm{x}$ & $\mathrm{x}$ & $\mathrm{x}$ & \\
\hline Composition & & & $x$ & $x$ & $x$ & $x$ & $x$ & \\
\hline Number of meetings & & & $x$ & & & $x$ & $x$ & \\
\hline Attendance & & & & & & & & \\
\hline Powers & & & $x$ & $x$ & & $x$ & $x$ & \\
\hline Activities actually realised & & & & & & & $x$ & \\
\hline & $\mathbf{0}$ & $\mathbf{0}$ & 4 & 3 & 2 & 4 & 5 & $\mathbf{0}$ \\
\hline
\end{tabular}

To conclude about the board of directors, it is important to stress that British Energy Group, Iberdrola and Enel inform on the periodical self-assessment conducted by their board: in various countries, it is recommended that the evaluation of effectiveness and efficiency is reported to the shareholders and the other stakeholders. Among the mentioned firms, Iberdrola offers the most careful description of persons and procedures analysed in the evaluation.

\section{c) Control Bodies and the Internal Control System}

Corporate governance systems are characterised by the role of control bodies, as determined by laws, codes of best practices and stock exchange regulations. Different levels of control involve many internal and external bodies, appointed by the shareholders' meeting or the board of directors.

The analysis of the disclosure on this theme has to consider the national peculiarities of each country, as well as the choices made by every firm within the corporate governance models permitted by the law.

First of all, a distinction among the two-tier system, the dual horizontal system and the one-tier system is necessary.

In the two-tier system of RWE the supervisory board plays the central role in corporate governance. This is clear in the company's communication: the firm starts its corporate governance chapter of the annual report introducing the supervisory board composition, its functions and activities. Moreover, RWE reminds that its supervisory board realises a periodical self-evaluation as requested by the code of best practices.

In the dual horizontal system, which is traditionally adopted in Italy and Japan, the shareholders' meeting appoints the board of auditors charged with functions of control on direction, organisational structures and internal procedures. Enel and Edison give effective information about their board of auditors composition, powers, meetings and nomination procedure. Enel stresses also that two members have been appointed on the basis of a ministerial suggestion, while Edison underlines the existence of the still mentioned shareholders' agreement ${ }^{23}$, which 
establishes the nomination procedure for the board of auditors. On the contrary, Chubu does not publish details on its board of auditors.

In the one-tier system of the other five companies, control is realised by the board of directors, particularly by the non-executive members. Nevertheless, the firms do not emphasise this function of board of directors in their reports, expect for mentioning that external directors meet in executive sessions.

Generally speaking, internal control is sufficiently analysed in the companies' documents on corporate governance, that include also information on risk management and internal audit. It probably depends on the relevance that codes of best practices and recommendations give to internal control and risk management. These documents establish that the board of directors (or the supervisory board) should periodically evaluate the effectiveness of internal control systems, with the support of the audit committee and with the co-operation of external consultants. However, just four companies inform about the evaluation of their internal control system (Eléctricité de France, British Energy Group, Aquila and RWE). Moreover, British Energy Group and Enel specify they have adapted their internal control system to the Sarbanes-Oxley Act provisions.

All the firms - except Chubu - pay attention to the audit committee in their corporate governance communication, usually indicating its composition ${ }^{24}$, the way of functioning (meetings and interaction with other control bodies), powers and tasks; on the contrary, the activities that the audit committee has realised in the year are rarely described.

Only Edison and Eléctricité de France underline that the audit committee refers to the board of directors (Table 9).

Table 9: Information on the Internal Control systems (ICS) and the Audit Committee

\begin{tabular}{|c|c|c|c|c|c|c|c|c|}
\hline & Enel & Edison & Iberdrola & EDF & BEG & Aquila & RWE & Chubu \\
\hline ICS evaluation & & & & $\mathrm{x}$ & $\mathrm{x}$ & $\mathrm{x}$ & $\mathrm{x}$ & \\
\hline ICS objectives & $\mathrm{x}$ & $\mathrm{x}$ & $\mathrm{x}$ & $\mathrm{x}$ & & & & \\
\hline Responsibility on ICS & $\mathrm{x}$ & $\mathrm{x}$ & $\mathrm{x}$ & $\mathrm{x}$ & $\mathrm{x}$ & $\mathrm{x}$ & & \\
\hline Major risks and risk management & & & $\mathrm{x}$ & $\mathrm{x}$ & $\mathrm{x}$ & $\mathrm{x}$ & $\mathrm{x}$ & \\
\hline Existence of the audit committee & $\mathrm{x}$ & $\mathrm{x}$ & $\mathrm{x}$ & $\mathrm{x}$ & $\mathrm{x}$ & $\mathrm{x}$ & $\mathrm{x}$ & \\
\hline Composition & $x$ & $x$ & $x$ & & $x$ & $x$ & $x$ & \\
\hline Number of meetings & $x$ & $x$ & $x$ & $x$ & $x$ & $x$ & $x$ & \\
\hline Attendance & $x$ & $x$ & & $x$ & $x$ & & & \\
\hline Powers and functions & $x$ & $x$ & $x$ & $x$ & $x$ & $x$ & $x$ & \\
\hline Activities actually realised & $x$ & $x$ & & $x$ & & $x$ & $x$ & \\
\hline $\begin{array}{r}\text { Persons/bodies to whom the } \\
\text { committee reports }\end{array}$ & & $x$ & & $x$ & & & & \\
\hline & 8 & 9 & 7 & 10 & 8 & 8 & 7 & $\mathbf{0}$ \\
\hline
\end{tabular}

As regards internal control, Enel and Edison also disclose details about the organisational, management and control model required by the Italian law on corporate criminal liability (legislative decree 231 of 2001), even if the Italian guidelines on corporate governance communication do not provide for this kind of information; furthermore, the Italian code of corporate governance has considered the organisational, management and control model as from the 2006 edition. 
Finally, details on statutory auditors are often disclosed with reference to extraaudit services; three companies (Edison, Iberdrola and Aquila) specify also the compensation paid to the auditors.

\section{d) Transactions Involving Private Interests of Directors and Officers}

The corporate governance communication should emphasise proper behaviour of directors and officers in the case of transactions determining a conflict of interests for them (Table 10). This is the case of related party transactions and internal dealing, that is to say respectively operations that can produce direct or indirect benefits for the director or the officer who realises them, and trading in company's stocks thanks to confidential information.

Table 10: Disclosure on Transactions Involving Related Parties, Handling of Confidential Information and Internal Dealing

\begin{tabular}{|c|c|c|c|c|c|c|c|c|}
\hline & Enel & Edison & Iberdrola & EDF & BEG & Aquila & RWE & Chubu \\
\hline \multicolumn{9}{|l|}{$\begin{array}{l}\text { Transactions involving } \\
\text { related parties }\end{array}$} \\
\hline List of operations & & & $\mathrm{x}$ & $\mathrm{x}$ & $\mathrm{x}$ & & $\mathrm{x}$ & \\
\hline Definition of related party & & & $\mathrm{x}$ & & & & & \\
\hline $\begin{array}{l}\text { Procedure to be followed by } \\
\text { the board of directors for } \\
\text { deliberating }\end{array}$ & $\mathrm{x}$ & $\mathrm{x}$ & $\mathrm{x}$ & & & & & \\
\hline \multicolumn{9}{|l|}{$\begin{array}{l}\text { Handling of confidential } \\
\text { information }\end{array}$} \\
\hline Description of the procedure & & $\mathrm{x}$ & $\mathrm{x}$ & & & & & \\
\hline $\begin{array}{l}\text { Addressees of the procedure } \\
\text { and their tasks and } \\
\text { responsibilities }\end{array}$ & & & & $\mathrm{x}$ & & & & \\
\hline \multicolumn{9}{|l|}{ Internal dealing } \\
\hline $\begin{array}{l}\text { Definition (or indication) of } \\
\text { people submitted to specific } \\
\text { rules ('relevant individuals') }\end{array}$ & $\mathrm{x}$ & $\mathrm{x}$ & & & & & & \\
\hline $\begin{array}{l}\text { Operations submitted to } \\
\text { disclosure duties }\end{array}$ & $\mathrm{x}$ & $\mathrm{x}$ & & & & & $\mathrm{x}$ & \\
\hline $\begin{array}{l}\text { Existence of company's } \\
\text { internal dealing code }\end{array}$ & & $\mathrm{x}$ & & $\mathrm{x}$ & & & & \\
\hline $\begin{array}{l}\text { Block periods and monetary } \\
\text { limitations }\end{array}$ & & $\mathrm{x}$ & & $\mathrm{x}$ & & & & \\
\hline & 3 & 6 & 4 & 4 & 1 & 0 & 2 & $\mathbf{0}$ \\
\hline
\end{tabular}

Italian and Spanish firms should inform the stakeholders about related party transactions, by means of their corporate governance report, as recommended. In this regard, the documents of Enel, Edison and Iberdrola contain satisfactory details on the internal procedure adopted for related party transactions: directors in actual or potential conflict of interests with the firm have usually to explain their position to the board of directors and then they should abstain from voting. The other companies tend to inform on related party transactions just from a financial point of view, inserting details in the notes to the financial statements. RWE underlines that no related party transaction has been conducted during the year. 
Edison, Enel and Iberdrola, together with Eléctricité de France, are the most careful companies in describing also:

- their procedures for confidential information handling;

- their rules on internal dealing ${ }^{25}$.

\section{e) Remuneration Systems}

Communicating directors' and officers' remuneration helps clarify how the resources produced by the company are divided among the stakeholders; moreover, this kind of information stresses risks and opportunities of the connection between the firm's purpose of value creation and the directors' and officers' personal interests. Indeed, the description of fix and variable compensation components is useful to clear up how the company motivates directors and officers.

The research has discovered moderate attention to the remuneration reporting (Table 11): just Chubu and Enel neglect this issue. In this regard, it is important to underline that the Italian guidelines on the corporate governance report require a general description of the remuneration system, but no details on the compensation level $^{26}$; however, a firm such as Enel, which is listed on the NYSE too, should communicate better, even on the grounds of the European recommendation that should come into force in 2006.

Table 11: Information on the Remuneration System

\begin{tabular}{|c|c|c|c|c|c|c|c|c|}
\hline & Enel & Edison & Iberdrola & EDF & $\mathrm{BEG}$ & Aquila & RWE & Chubu \\
\hline \multicolumn{9}{|l|}{ Cash remuneration } \\
\hline $\begin{array}{l}\text { Global remuneration of } \\
\text { directors and top managers }\end{array}$ & & & $\mathrm{x}$ & $\mathrm{x}$ & & & & \\
\hline $\begin{array}{l}\text { Individual remuneration of } \\
\text { directors and top managers }\end{array}$ & & $\mathrm{x}$ & & $\mathrm{x}$ & $\mathrm{x}$ & $\mathrm{x}$ & $\mathrm{x}$ & \\
\hline $\begin{array}{l}\text { Bonus payments and profit } \\
\text { sharing }\end{array}$ & & $\mathrm{x}$ & $\mathrm{x}$ & $\mathrm{x}$ & $\mathrm{x}$ & $\mathrm{x}$ & $\mathrm{x}$ & \\
\hline \multicolumn{9}{|l|}{$\begin{array}{l}\text { Stock grants and stock } \\
\text { options plans }\end{array}$} \\
\hline $\begin{array}{l}\text { Number of shares and options } \\
\text { held by directors and top } \\
\text { managers }\end{array}$ & & $\mathrm{x}$ & $\mathrm{x}$ & $\mathrm{x}$ & $\mathrm{x}$ & $\mathrm{x}$ & $\mathrm{x}$ & \\
\hline $\begin{array}{l}\text { Information on shares and } \\
\text { options assigned, exercised } \\
\text { and non-exercised in } 2005 \\
\end{array}$ & & $\mathrm{x}$ & & & & $\mathrm{x}$ & & \\
\hline \multicolumn{9}{|l|}{ Other compensations } \\
\hline $\begin{array}{ll}\text { Remuneration from other } \\
\text { companies of the Group }\end{array}$ & & $\mathrm{x}$ & $\mathrm{x}$ & & & & & \\
\hline Pension or retirement plans & & & & & $\mathrm{x}$ & $\mathrm{x}$ & & \\
\hline & $\mathbf{0}$ & 5 & 4 & 4 & 4 & 5 & 3 & $\mathbf{0}$ \\
\hline
\end{tabular}

The information on individual compensation of directors and officers is disclosed by five companies (the exceptions are Enel, Chubu and Iberdrola) and is wellstructured, with indication of fix and variable components, benefits and sometimes pension plans. In particular, five out of the six firms with bonus payments and profit 
sharing explain the criteria adopted to assign the variable parts of the remuneration ${ }^{27}$ when pre-established corporate or individual targets are achieved.

The allocation of stock grants and stock options to executive directors and officers is a common practice, but the communication can be still improved as concerns the conditions of stock options exercising (time, price, etc.).

\section{f) The Ownership Structure, the General Meeting of Shareholders and Investor Relations}

Corporate governance communication should inform the stakeholders on the ownership structure and the existence of relevant shareholders. However, the Spanish recommendations expressively require companies to insert these details in their corporate governance report: in this regard, Iberdrola has indeed a complete report.

Information on how the general meeting of shareholders operates and how the company interacts with shareholders and investors by means of a professional investor relations department is recommended only by the Italian guidelines. In fact, non-Italian firms do not publish satisfactory information on these themes: they usually just mention their corporate website as a means of contact with investors and other stakeholders (Table 12).

Table 12: Information on The General Meeting of Shareholders and Investor Relations (IR)

\begin{tabular}{|c|c|c|c|c|c|c|c|c|}
\hline & Enel & Edison & Iberdrola & EDF & BEG & Aquila & RWE & Chubu \\
\hline Voting procedures & $\mathrm{x}$ & & $\mathrm{x}$ & $\mathrm{x}$ & & $\mathrm{x}$ & $\mathrm{x}$ & \\
\hline Shareholders' agreements & $\mathrm{X}$ & $\mathrm{X}$ & $\mathrm{X}$ & $\mathrm{X}$ & & & & \\
\hline IR objectives & $\mathrm{X}$ & $\mathrm{x}$ & & & & & & \\
\hline IR actual activities & & $\mathrm{x}$ & $\mathrm{x}$ & & & & & \\
\hline $\begin{array}{l}\text { Information about the } \\
\text { company's website as a means } \\
\text { of interaction with the } \\
\text { stakeholders }\end{array}$ & $\mathrm{X}$ & $\mathrm{x}$ & $\mathrm{x}$ & $\mathrm{x}$ & $\mathrm{x}$ & $\mathrm{x}$ & $\mathrm{x}$ & \\
\hline & 4 & 4 & 4 & 3 & 1 & 2 & 2 & $\mathbf{0}$ \\
\hline
\end{tabular}

Companies pay higher attention to voting procedures in the general meeting of shareholders, even if three of them (Edison, British Energy Group and Chubu) do not mention on-line voting and proxy voting.

As concerns shareholders' agreements, three firms declare not to know their existence, while Edison publishes some abstracts of them in its corporate governance report.

\section{Emerging Issues}

The research permits us to deepen some relevant issues concerning the effectiveness of corporate governance communication and its possible evolution, although few countries and companies have been considered.

First, the analysis of laws, recommendations and company behaviour stress that we are still far from a formal and substantial shared model of communication. 
Particularly, the attention to corporate governance communication seems to be inhomogeneous and little connected to the economic development of a country. In this regard, it is important to underline the case of Germany and Japan, which have shown until now very little interest in promoting corporate governance communication. Besides, the corporate governance report is recommended only in Italy and Spain, and what's more by means of non-mandatory guidelines that are exclusively addressed to listed companies.

Anyway, the awareness of the role of corporate governance for durable trustbased relationships and positive interaction between the firm and its stakeholders is recent, and it has been sometimes accelerated by episodes of fraud and research of private benefits, trampling on proper principles of transparency and social equity (Enron, WorldCom, Merck, Cirio, Parmalat, Vivendi, etc.).

The corporate communication is still changing and in the future there could be higher uniformity of conduct on an international scale. This prediction seems to be confirmed by the increasing globalisation of financial markets and the modifying ownership structures of national stock exchanges, sometimes as a consequence of mergers and acquisitions.

Higher international uniformity of corporate governance communication is anyhow desirable; at this moment, however, it is still difficult to identify possible steps, because of the scanty international co-operation on this issue. Moreover, different conducts could be adopted: for example, a common model of corporate governance communication could be established for the largest companies, which involve relevant economic interests; alternatively, specific models for different countries could be developed, but they should all be based on shared rules and principles of transparency and stakeholder protection.

Anyway, more intensive international co-operation would be helpful, in order to reflect the current globalisation of markets and information in the corporate governance communication, guaranteeing opportunities of comparison. Such a condition is particularly significant for energy firms, the success of which is determined by the ability to activate and stimulate international relationships and influenced by world-scale social and economic phenomena (oil price, energy sources, wars and revolts in countries supplying raw materials and services, etc.).

The importance of sufficiently accurate and detailed recommendations on corporate governance communication is confirmed by the empirical research. With reference to the eight companies investigated:

- corporate governance reporting is clearer and more complete when guidelines, detailed models or precise recommendations exist;

- the quantity and the quality of information get worse when leading indications decrease.

Moreover, it should be important to go over the focalisation on listed firms, typical of current recommendations, in order to adopt a different approach based on the protection of all stakeholders in accordance with proper principles of business administration direct to protect from different risk typologies. With reference to public utilities, for example, environmental and supply risks are inborn in nonoptimum governance. 
Finally, the effectiveness of corporate governance communication requires a business culture oriented to improve constantly the quality of information, on the basis of transparency and completeness of the messages divulged to all the company stakeholders. The selection of contents has to adequately combine mandatory and voluntary ones, according to a defined communication project finalised to satisfy informative and evaluational external expectations.

The research shows different degree of detail from a company to another as regards specific contents of corporate governance communication, even considering firms of the same country and subject to the same recommendations. For instance, Enel - differently from Edison - gives no details in its corporate governance report for the year 2005 with reference to the remuneration system, although its complexity. Companies have to go over the reticence that seems to prevail today, with opaque information on critical contents; on the contrary, firms have to communicate transparently to permit that all the stakeholders can assess the effectiveness of corporate governance.

Transparency is in fact a duty, an opportunity and a preliminary condition of effectiveness in the relationships between the company and the stakeholders. In this regard, the ability of corporate governance boards to combine requirements of transparency and confidentiality in external communication is fundamental for the company success.

\section{Notes}

${ }^{1}$ In some countries the debate on corporate governance began in the first half of the twentieth century, while in other countries - Italy included - business administration has its starting point in governance logics. For instance, it is enough to mention Berle and Means' book of 1932 on The modern corporation and private property and the establishment of the Cohen Committee in Great Britain in 1945 to understand the importance of corporate governance, which has determined long development of the studies on this issue. Since the Nineties, however, corporate governance principles have required to be defined again in order to guarantee the effectiveness of company direction and control, after heavy corporate scandals all over the world. In Italy, in 1927 Zappa defined the firm as a functioning economic coordination, established and directed in order to satisfy human needs. See Zappa G. 1927, Tendenze nuove negli studi di ragioneria, Istituto Editoriale Scientifico, Milan, p. 30.

2 The analysis of company-stakeholder relationships and connected conditions of effectiveness is not true; however, its re-examination is quite recent and it is realised by means of a new approach based on harmonious governance, social and environmental responsibility, communication, intangible assets and links with the management control system.

Particularly, progressive development of company systems, market globalisation and increasing lack of ethics have more and more stressed the need to recover a global vision that puts emphasis on the importance of company-stakeholder relationships, setting off the connections among expectations, decisions and actions that determine together the corporate evolution. See Salvioni D.M. 2004, Efficacia aziendale, processi di governo e risorse immateriali, in Salvioni D.M. (ed.), Corporate governance, controllo di gestione e risorse immateriali, FrancoAngeli, Milano, pp. 12 13.

${ }^{3}$ Institutional communication is oriented to manage approval as regards how corporate governance is exercised and with reference to consequent economic, social and environmental performance. This form of communication concerns the company on the whole and it can satisfy all stakeholders' needs of information, if it is properly divulged. 
${ }^{4}$ As regards Spain, the first recommendations on corporate governance communication were contained in the Aldama Report (the code of best practices published in 2003) and considered only the contents of the corporate governance report. In 2004, the Spanish exchange commission (Comisión Nacional del Mercado de Valores) introduced a mandatory format, composed of tables to be filled in and questions to be answered. The mandatory format should guarantee complete reporting, because lack of information would be noticed even by inexpert readers.

In Italy, as well as in Spain, recommendations on corporate governance communication have become more intensive in time, from 2002 to 2004. At first, Borsa Italiana SpA (the Italian Stock Exchange) strengthened its initial recommendations; after that, Assonime and Emittenti Titoli (who represent Italian stock companies) have enriched them, introducing also summarising tables in order to better the comparability of listed companies' corporate governance reports.

${ }^{5}$ The 'document de référence', published by French companies at the end of the year, contains all economic, accounting and legal information on listed firms.

The 'proxy statement' is the document - published by US firms and transmitted to the Securities and Exchange Commission too - by means of which shareholders are informed, convened for the general meeting and solicited to vote. The proxy statement contains information on the board of directors' structure, but it neglects the activities actually realised in the year.

${ }^{6}$ German listed companies must declare in a separate statement the degree of compliance with the code of best practices. The company annual report and the website include few details on the corporate governance system.

In Japan, the code of best practices affirms transparency and completeness of disclosure, but it doesn't stress the role of corporate governance communication. No declaration is required to listed companies as concerns corporate governance.

${ }^{7}$ The typical functions of internal committees are: to implement the board of directors' decisions (executive committee); to formulate nomination proposals and to verify independence and integrity of candidates and directors (nomination committee); to delineate the most effective remuneration system and to propose compensations (remuneration committee); to assist the board in projecting and implementing the internal control system (audit committee). Other consultative and proposing tasks can be assigned to these committees or to others, intentionally established: for example, a committee charged with responsibilities of supervision on the exercise of corporate governance, or entrusted with studying, realising and verifying the company strategies.

${ }^{8}$ It's important to underline that the interest in corporate governance issues in the United States has been awaken by the Enron scandal.

9 The best practices of corporate governance recommend listed companies to appoint a lead independent director when the chairman of the board is an executive director. The lead independent director is an independent member of the board who must coordinate the activities of all the independent directors and promote a constructive dialogue with the executive directors.

${ }^{10}$ The companies with a two-tier system - introduced in 2003 by the Italian law - should divulge information on the supervisory board.

${ }^{11}$ The choice depends on the relevance recognised to compensation issues, since the remuneration system is often considered as useful to align directors' private interests with the shareholders' purposes of value creation. Anyway, expository choices should take in account the evident integration of this topic with other details that are published in the corporate governance report or in the financial report, in order to obtain complete and coordinate information on remuneration issues

12 See: Fiori G., Tiscini R. (ed.) 2005, Corporate governance, regolamentazione contabile $e$ trasparenza dell'informazione aziendale, FrancoAngeli, Milan, pp. 100-126; Melis A. 1999, Corporate governance. Un'analisi empirica della realtà italiana in un'ottica europea, Giappichelli, Turin; Charkham J.P. 1994, Keeping good company. A study of corporate governance in five countries, Oxford University Press, Oxford.

13 The French share belongs indirectly to Eléctricité de France (through WGRM, totally controlled). 
${ }^{14}$ Chubu is reforming its corporate governance system. Modifications should concern: the board of directors composition; the introduction of an advisory board to support the president; appointment procedures; separation of powers between directors and officers; mutual young personnel exchange between companies inside the Group.

${ }^{15}$ In the tables, the existence of information is signalled by an ' $\mathrm{x}$ '. The order of countries depend on the existence and intensity of recommendations on corporate governance reporting: at first, Italy and Spain, then France, Great Britain and the US, and finally Germany and Japan.

${ }^{16}$ Eléctricité de France states that none of its directors has been convicted of fraud or declared bankrupt in the past five years.

${ }^{17}$ The lack of information can be justified only with reference to implicit aspects of the corporate governance system adopted by a company. For example, RWE doesn't underline that members of its management board are executive directors, because this is obvious.

18 According to the request of their stock exchanges, British Energy Group and Aquila refer to their websites as concerns committee charters.

${ }^{19}$ Some companies publish details on composition and tasks of the ethics committee, the EHS committee, the nuclear power committee and the financial disclosure committee.

${ }^{20}$ In Iberdrola there is only a committee for both nomination and remuneration.

${ }^{21}$ According to the agreement signed by the two major shareholders, Edison's board of directors has twelve members. The Italian shareholder Meldi appoints six directors (one of whom independent), as well as the French shareholder Eléctricité de France, through WGRM. The same ratio is valid to appoint the committee members. Moreover, Meldi appoints the chairman and Eléctricité de France appoints the executive director and CEO.

${ }^{22}$ In tables concerning board committees, italic type is used in case of details the search of which depends on the existence of the committee itself.

${ }^{23}$ According to the shareholders' agreement, each of the two major shareholders appoints one full member and one alternate; the other members are appointed on the basis of lists proposed by minority shareholders. The chairman is chosen by the major shareholders between the two full members they have appointed.

${ }^{24}$ In the German system, the audit committee is appointed inside the supervisory board.

${ }^{25}$ For instance, the following limitations are specified in several internal dealing codes:

- block periods: the periods in which directors and managers can't buy and sell company's shares and certificates; these periods usually cover the days immediately before the disclosure of quarter and annual results;

- monetary limits: the global or individual value of transactions that obliges the company to inform the market.

Limits are normally introduced by the national stock exchanges, but companies can apply them in a stronger way in the interest of the stakeholders.

${ }^{26}$ Also the Italian guidelines promoted by Assonime and Emittenti Titoli refers to the notes to the financial statements for details, if the company considers them useful.

27 According to the most common practice, non-executive and independent directors receive no variable compensation, to avoid that they could have a spur to intentionally intervene in operational management.

With reference to Eléctricité de France, it is interesting that the company underlines the prohibition to pay variable compensation to the directors appointed by the French State and by the employee shareholders. 